\title{
Discovery of Blaesoxipha litoralis Villenueve, 1911 (Diptera, Sarcophagidae) in Korea
}

\author{
By Soung Ho PARK*, Rokuro KANO** and Dong Woo PARK*** \\ * Department of Science Faculty, Chinju National Agricultural College, \\ Chinju, Korea. \\ ** Department of Medical Zoology, Tokyo Medical and Dental University, \\ Bunkyo-ku, Tokyo 113, Japan. \\ *** Department of Entomology, National Institute of Health, Seoul, Korea.
}

(Received: November 25, 1971)

The previous studies (Park, 1968 and 1970 have recorded two Korean species of Blaesoxipha, namely $B$. filipjevi Rohdendorf, 1928 and B. katoi Park and Kano, 1968.

As the third species of this genus from Korea, B. litoralis Villeneuve, 1911 is newly reported in this paper.

Blaesoxipha litoralis Villeneuve, 1911.

Deutsch. Ent. Zeitsch., 1911: 129

\section{Male}

Body length : $6-8 \mathrm{~mm}$

Head: Width of frons about one-fifth of an eye; frontal vitta black; parafrontals and parafacials with silvery pollen; antennae dark brown with silvery pollen, length of 3 rd segment 2 times that of 2 nd segment; genae black, silverly pollinose with numerous black hairs; frontal bristles 11 pairs; metacephalon with grayish white hairs; 2 rows of postocular setae present; palpi black.

Thorax: Scutum with silvery pollen and 3 black longitudinal stripes; acrostichal bristles $3+5$ (anterior 3 postsutural acrostichal bristles indistinct); dorsocentral bristles $4+3$; intra-alar bristles $1+3$; humeral bristles 3 ; notopleural bristles 4 ; presutural

*䄭 星湖：大韓民国晋州農化大学動物（慶南晋 州市七岩洞 92)

**加納六郎：東宗医科歯科大学医動物学教室（東 京都文京区湯島）

****种絧雨：大韓民国国立保健研究院衛生部昆虫 种（Seoul 特別市西大門区） bristle 1 ; supra-alar bristles 3 ; posthumeral bristles 2 ; a pair of subapical scutellar bristles longer than other scutellar bristles; prosternum hairy; propleuron bare.

Wings: Hyaline; $\mathrm{R}_{1}$ bare; $\mathrm{R}_{4+\overline{5}}$ with a row of about 7 short setae located dorsally on the basal half from the basal node to $\mathrm{r}-\mathrm{m} ; 3$ short bristles on ventral surface of basal node of $\mathrm{r}-\mathrm{m}$ : basicostal scale light brown; halter brown; squamae light brown.

Legs: Black; fore femur with a pair of rows of bristles on posterodorsal surface and a row of long bristles on posteroventral surface ; fore tibia with 2 bristles on basal half of anterodorsal surface, 1 bristle on posteroventral surface at $1 / 3$ distance from distal end ; mid femur with 3 or 4 bristles on basal halves and a row of comb-like bristles on distal halves of posteroventral and anteroventral surfaces; mid tibia with 2 bristles each on posterodorsal and anterodorsal surfaces and 1 bristle on ventral surface at $1 / 3$ from distal end; hind femur with a row of bristles on anterodorsal surface and a row of bristles each on anteroventral and posteroventral surfaces; hind tibia with a row of bristles on anterodorsal surface (2 bristles long), 2 strong bristles on posterodorsal surface, 2 bristles on anteroventral surface.

Abdomen: Black with silvery checkered pattern; median marginal bristles absent on 3 rd tergite; several pairs of marginal bristles on 4 th and 5 th tergites; 1 st and 2 nd genital tergites light brown; forceps orange; 

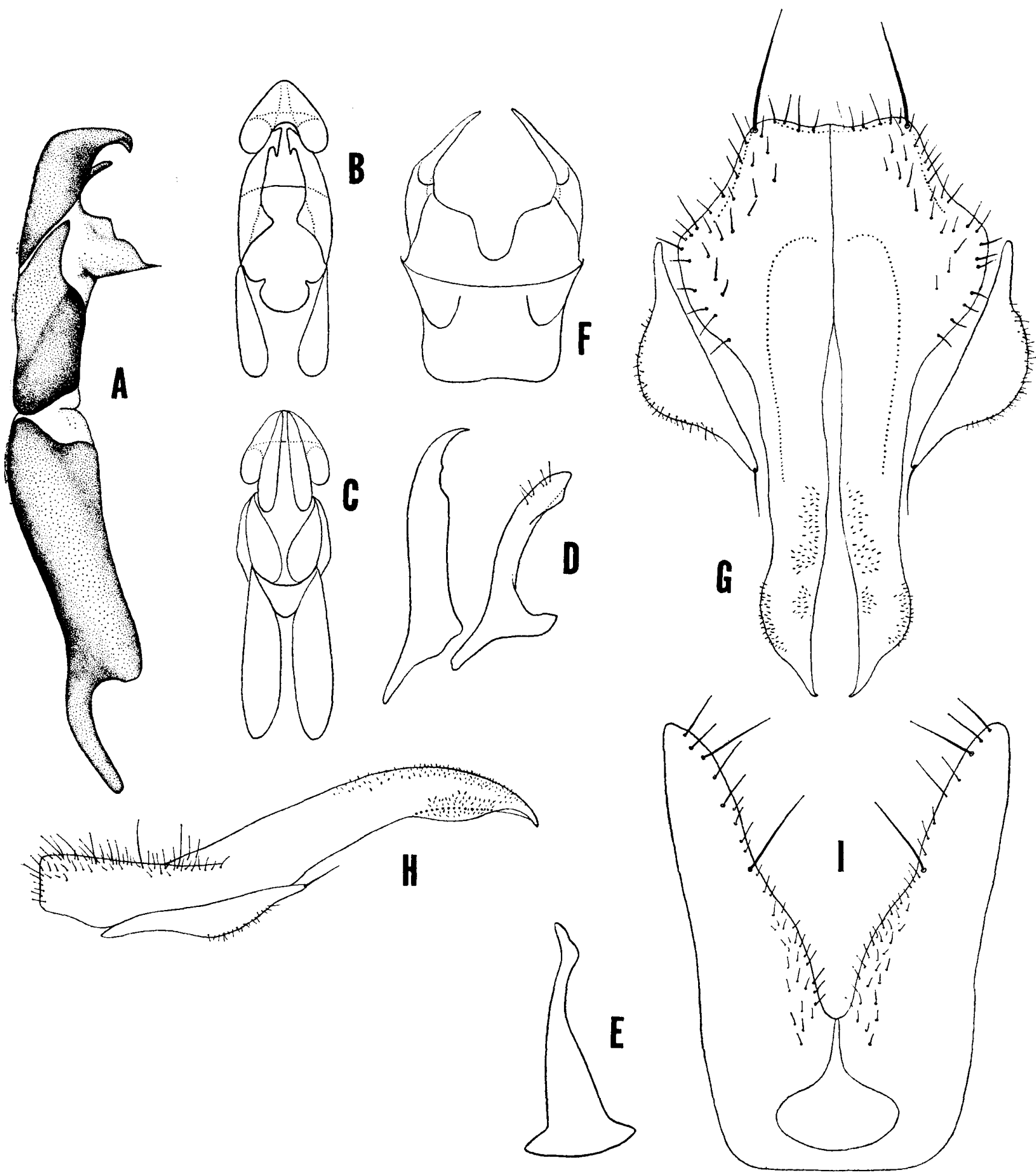

Fig. 1 Blaesoxipha litoralis Villeneuve, 1911

A : Lateral view of penis. B: Dorsal view of penis. C: Ventral view of penis. D: Parameres. E: Ejaculatory apodeme. F: Vinculum. G: Hind view of forceps. H: Lateral view of forceps. I: 5 th sternite of male. (Leg. S. H. Park) 

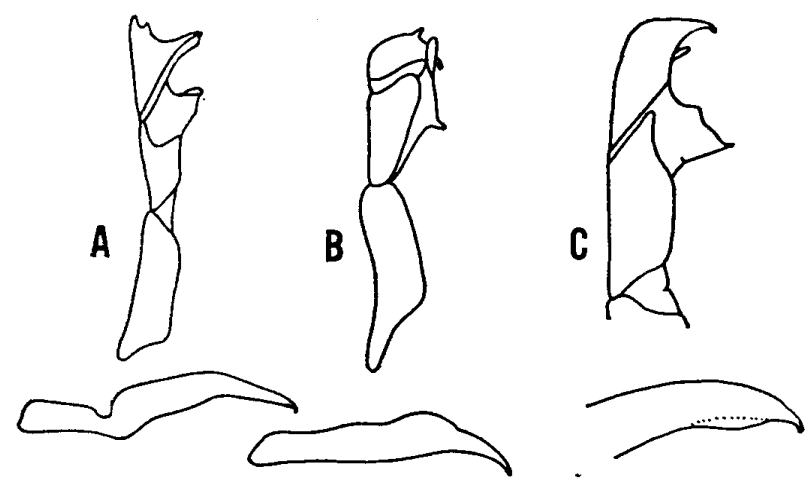

Fig. 2. Penis and forceps

A : Blaesoxipha flipjevi Rohdendorf. B: B. katoi Park and Kano. C : B. litoralis Villeneuve.

5 th sternite, forceps, parameres and penis as shown in Fig. 1 (A-I).

Distribution: Europe, East Asia, Iran.

Locality: Nogodan (Mt. Jiri), 16-18 Aug. 1970, 22 males collected by S. H. Park, 5 males collected by D. W. Park.

Remarks: This species was found on rocks, stones or ground along the mountain paths about 500 meters above sea level. It did not gather on animal carcasses.

\section{REFERENCES}

Kano, R., G. Field and S. Shinonaga (1967): Fauna Japonica Sarcophagidae. 11-16 pp. Biogeogra. Soc. Jap., Tokyo.

Kurahashi, H. (1964): Discovery of Blaesoxipha filipjevi Rohdendorf in Japan (in Japanese). Kontyu, 32 (3) : 366.

Park, S. H. and R. Kano (1968): Description of one new species of Sarcophagid flies from Korea. Jap. J. Sanit. Zool., $19(1): 1-3$.

Park, S. H. (1970) : Studies on flies in Korea. Korean J. Zool., 13 (1) : 26-28.

Rohdendorf, B. B. (1937): Faune de l'URSS, Insects Diptéres, XIX (1) : 94-99.

Séguy, E. (1941): Encyclopédie Entomologique XXI, Mouches Parasites II, 197-198 pp. Paris.

Shinonaga, S. and Y. Matsudaira (1970): Three new species of the Sarcophagid flies from Japan (Diptera, Sarcophagidae, Sarcophaginae). Jap. J. Sanit. Zool., $21(2): 88-89$.

\section{摘 要}

韓国産 Blaesoxipha 属は1968年に朴星湖によっては じめて報告され，1970年までに，B. katoi，B. filipjeri の 2 種が記録された. 1970年 8 月, 南部で Blaesoxipha

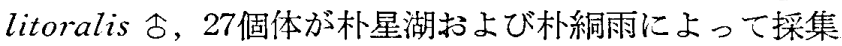
された. B. litoralis は今まで Europe, USSR, Iranな どに分布していることが知られており，韓国でははじめ て発見されたものである。本種が追加されて，韓国産 Blaesoxipha 属のニクバエは 3 種になった。 